\title{
HUBUNGAN PEMBANGUNAN EKONOMI TERHADAP KUALITAS LINGKUNGAN HIDUP DI PROVINSI JAWA TIMUR
}

\author{
Selly Febriana ${ }^{1}$, Herman Cahyo Diartho ${ }^{2}$, Nanik Istiyani \\ Fakultas Ekonomi dan Bisnis Universitas Negeri Jember \\ febriancelot@gmail.com
}

\begin{abstract}
This research aims to know the relationship of economic development focused on the growth rate of agriculture, industrial and transportation toward index environmental quality of life in the East Java. The model is used in this study is Vector Error Correction Models (VECM) and method selected in this research is Granger Causality. The research of the method of analysis Granger Causality show that a causal relationship or on-both-sides relationship between variabels the growth rate of indusrial sector toward Index Environmental Quality of Life with a value as big 0.0470 significant level 5\%. Transportation sector has a causal relationship with value as big 0.0000 toward Index Environmental Quality of Life significant level 5\%. The Agricultural has a causal relationship with value as big 0.0000 toward index environmental quality of life significant level 5\%. Meanwhile, the hypothesis Environmental Kuznet Curve proven in the East Java shaped U-inverse slope.
\end{abstract}

Keywords: Economic Development, Index Environmental Quality of Life, Environmental Kuznet Curve, Sectors Industrial, Agriculture, and Transportasi.

\section{JEL Classification:}

\section{PENDAHULUAN}

Degradasi lingkungan telah menjadi masalah penting diberbagai penjuru wilayah di Indonesia. Munculnya kepedulian publik atas masalah lingkungan telah memicu upaya untuk memahami lebih jelas dan mulai mengambil langkah serta alasan sebenarnya tentang masalah maupun sebab akibat dari degradasi lingkungan.

Pada awal 1970-an isu lingkungan menjadi pilar penting dalam pembangunan ekonomi. Bahkan, hal ini telah menjadi tujuan utama dari berbagai kebijakan pembangunan, baik dalam tingkat global maupun nasional. Satu momen penting yang menganggap lingkungan sebagai tujuan sekaligus sebagai suatu kerangka dalam proses pembangunan - hal tersebut terdapat dalam laporan World Commision for Environment and Development atau lebih dikenal sebagai Komisi Brundtland.

Tuntutan di era global dengan sederetan tantangan yang dihadapi seperti isu prioritas pembangunan yang menekankan pada integrasi pembangunan berwawasan lingkungan. Adanya pola strategi pembangunan konvensional menjadi serangkaian 
tantangan bagi para pengambil kebijakan yang berkaitan dengan adanya eksplorasi besar - besaran terhadap sumber daya alam dan lingkungan. Eksplorasi ini dapat mengakibatkan ekstrasi yang dapat melebihi ambang batas daya dukung lingkungan. Pada gilirannya akan berujung pada masalah baru pada lingkungan itu sendiri, seperti; peningkatan polusi, kekeringan berkepanjangan, penurunan beban pada kandungan air, serta menurunnya kandungan pangan merupakan dampak nyata yang perlu diperhatikan lebih dalam.

Masalah penting dalam pembangunan ekonomi adalah bagaimana menghadapi trade-off antara pembangunan dengan upaya pelestarian lingkungan (Drews \& Bergh, 2017). Pembangunan yang tidak memperhatikan kedua aspek tersebut akan mengakibatkan masalah dikemudian hari. Secara ringkas, pembangunan ekonomi yang semata - mata hanya merujuk kepada sebuah keuntungan tanpa mempertimbangkan keberlangsungan alam dan lingkungan tidak akan membawa dampak negatif bagi alam saja melainkan pada manusia juga.

Dalam penelitian ini, fokus kepada tiga sektor utama yang memiliki kontribusi besar terhadap pertumbuhan ekonomi di Jawa Timur antara lain; Sektor Industri, Sektor Pertanian dan Sektor Transportasi. Ketiga sektor tersebut sangat berkaitan dan saling memiliki dampak trickel down effect dan backswash effect dari proses kegiatan ekonomi.

Tabel.1 PDRB Sektor Industri, Pertanian, dan Transportasi Provinsi Jawa Timur Menurut Lapangan Usaha 2013 - 2017 (Milliar Rupiah)

\begin{tabular}{lccccc}
\hline & 2013 & \multicolumn{1}{c}{2014} & \multicolumn{1}{c}{2015} & 2016 & 2017 \\
\hline Industri & 397997,7 & 445279,8 & 495751,8 & 536442,9 & 586258,6 \\
Pertanian & 186038,3 & 208613,6 & 230942,5 & 249457,2 & 258428,1 \\
Transportasi & 42435,2 & 50000,7 & 56632,8 & 62775,4 & 69176,4 \\
\hline
\end{tabular}

Sumber: Badan Pusat Statistik (data diolah)

Data pada tabel diatas menunjukkan pertumbuhan pendapatan dari sektor Industri, Pertanian dan Transportasi dapat dilihat bahwa trend pertumbuhan dari ke tiga sektor menunjukkan tren pertumbuhan positif. Namun, apa yang terjadi dalam kualitas lingkungan hidup atas kegiatan ekonomi yang digambarkan dalam data diatas? Dibawah ini akan dipaparkan data mengenai kondisi lingkungan hidup Provinsi Jawa Timur sebagai data pembanding sekaligus masalah yang akan dibahas dalam penelitian ini.

Tabel.2 Indeks Kualitas Lingkungan Hidup, Air dan Udara di Provinsi Jawa Timur 2013 - 2017 (persen)

\begin{tabular}{lllrrr}
\hline & 2013 & 2014 & 2015 & 2016 & 2017 \\
\hline Indeks Kualitas Udara & 72,45 & 73,20 & 89,21 & 83,20 & 85,49 \\
Indeks Kualitas Air & 49,10 & 49,11 & 50,33 & 49,07 & 49,17 \\
Indeks Kualitas Lingkungan & 56,25 & 56,48 & 61,70 & 63,98 & 60,70 \\
Hidup (IKLH) & & & & & \\
\hline
\end{tabular}

Berdasarkan data pada tabel.2 dapat di tarik benang merah bahwa tingginya tingkat pendapatan tidak dapat menjamin membaiknya kualitas lingkungan. Jika dilihat dari Indeks Kualitas Air dimana pada tahun 2015 merupakan nilai indeks 
tertinggi sebesar 50,33\% dan kemudian turun, sehingga pada tahun 2017 Indeks Kualitas Air menjadi 49,17\%. Sedangkan pada Indeks Kualitas Lingkungan Hidup mengalami tren yang terus meningkat dari tahun ke tahun namun tidak begitu drastis. Pada tahun 2017 Indeks Kualitas Lingkungan Hidup sebesar 60,70 artinya, berada pada predikat cukup baik.

Nilai predikat ini nantinya sebagai indikator tolak ukur dalam pengambilan kebijakan tentang masalah pengolahan dan perlindungan kualitas lingkungan. Ambang batas yang ditetapkan sesuai dengan Peraturan Undang - undang Nomor 32 Tahun 2009 tentang Perlindungan dan Pengolahan Lingkungan Hidup.

Dampak proses pembangunan selain dapat meningkatkan pendapatan dari proses kegiatan ekonomi itu sendiri juga dapat menyebabkan eksternalitas negatif sebagai bentuk dari biaya sosial yang timbul akibat aktivitas ekonomi. Peraturan Pemerintah Republik Indonesia Nomor 74 Tahun 2001 tentang Pengolahan Bahan Berbahaya dan Beracun menyatakan bahwa dengan meningkatnya kegiatan pembangunan di berbagai bidang tertentu, terutama di bidang perdagangan dan industri terdapat kecenderungan semakin meningkatnya penggunaan bahan berbahaya dan beracun.

Atas dasar regulasi diatas serta data dan berbagai masalah kondisi yang ada di lapangan maka dilakukan kajian tentang bagaimana pengaruh pembangunan terhadap kualitas lingkungan hidup. Hypotesis Environmental Kuznet Curve telah banyak digunakan untuk meneliti bagaimana kegiatan aktivitas ekonomi dapat berpengaruh terhadap lingkungan. Teori ini dikembangkan atas dasar permintaan lingkungan yang pada gilirannya akan meningkatkan pengawasan sosial dan regulasi pemerintah (Mason dan Swanson, dalam Idris, 2010).

\section{TINJAUAN PUSTAKA}

\section{Pembangunan Ekonomi}

Pembangunan ekonomi di pandang sebagai suatu proses pembangunan yang terjadi secara terus menurus dan bersifat dinamis. Pembangunan ekonomi juga di pandang sebagai suatu proses transformasi yang ditandai secara struktural. Perubahan tersebut terjadi akibat dari kegiatan ekonomi dan adanya faktor yang berpengaruh atas perubahan peran sektor ekonomi dalam upaya pembentukan pendapatan nasional.

Schumpeter, mendefinisikan pembangunan ekonomi sebagai perubahan yang spontan dan terputus - putus (discontinuous) pada saluran arus sirkuler yang mana merupakan gangguan terhadap keseimbangan yang selalu mengubah dan mengganti keadaan keseimbangan sebelumnya.

Pembangunan ekonomi menjadi penompag utama atas keberhasilan suatu negara, namun dilain sisi pembangunan juga menjadi problem besar yang harus di hadapi terutama dampak dari proses kegiatan pembangunan terhadap kualitas lingkungan hidup. 


\section{Pertumbuhan Ekonomi}

Simon Kuznets, (Todaro, 2000) menyatakan bahwa pertumbuhan ekonomi ditandai oleh kenaikan kapasitas dalam jangka panjang dalam menyediakan berbagai barang ekonomi kepada masyarakat dan hal tersebut terwujud dengan adanya kenaikkan output nasional secara terus - menerus dan disertai dengan kemajuan teknologi.

Pembangunan ekonomi dan pertumbuhan ekonomi saling bersinergi dalam mencapai tujuan pembangunan nasional. Namun, jika dua aspek tersebut tidak memperhatikan sisi kelestarian lingkungan akan muncul masalah baru di kemudian hari. Adanya kemajuan teknologi yang tidak ramah lingkungan dapat membahayakan habitat alamnya. Kegiatan proses produksi tidak ramah lingkungan sebagai bentuk upaya dari kenaikan output, selain dapat meningkatkan pendapatan juga akan menghasilkan biaya sosial yang cukup besar.

\section{Enironmental Kuznet Curve}

Teori Environmental Kuznets Curve (EKC) menyatakan bahwa kasus di negara berkembang seiring dengan berjalannya waktu, adanya kemajuan teknologi dapat merusak kelestarian alam dan lingkungan. Sedangkan, di negara maju seiring dengan berjalannya waktu adanya kemajuan teknologi dapat meningkatkan kelestarian lingkungan hidup. Teori ini dikenal sebagai teori pertama yang menggambarkan bagaimana hubungan antara tingkat pertumbuhan ekonomi dengan degradasi lingkungan. Teori ini menyatakan bahwa ketika pendapatan suatu negara masih tergolong rendah, maka perhatian negara tersebut - baik dalam sisi produksi adanya investasi yang dapat mendorong terjadinya peningkatan pendapatan dengan mengesampikan permasalahan lingkungan. Akibatnya pertumbuhan pendapatan akan diikuti dengan tingkat polusi dan kemudian akan menurun dengan pertumbuhan yang Tetap berjalan.

\section{Gambar 1}

\section{Kurva Environmental Kuznet Curve}

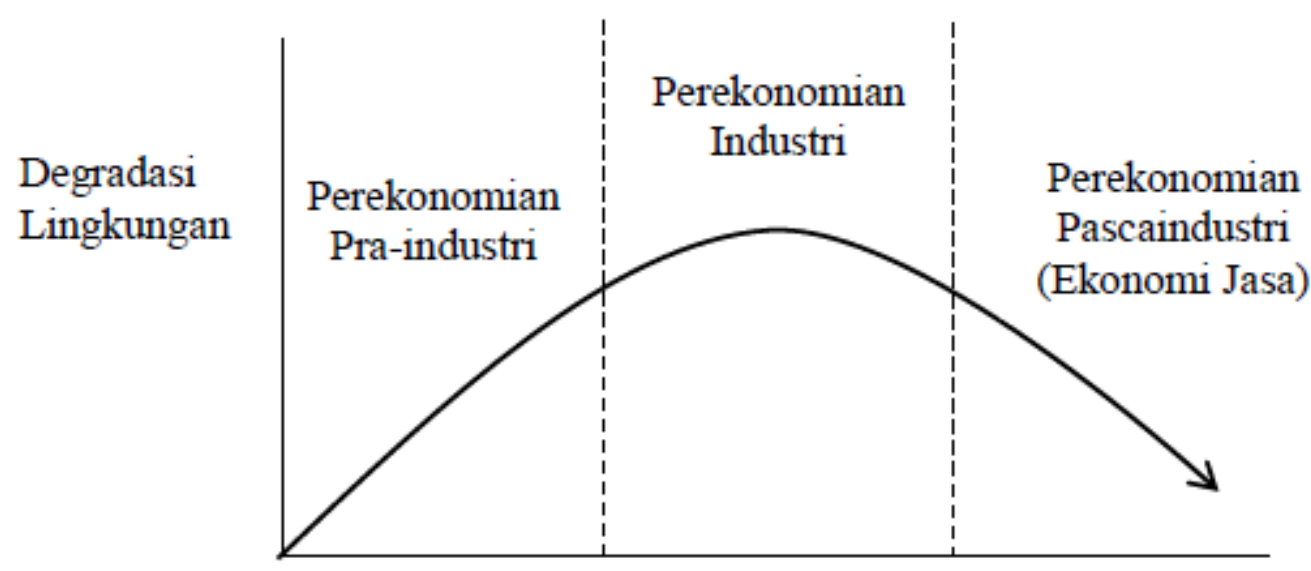

Pertumbuhan Ekonomi

Sumber: Panayaotuo, 2003 
Environmental Kuznet Curve dibagi menjadi tiga tahapan, (Panayotou, 2003) antara lain; pertama, awal proses pembangunan ekonomi akan diikuti dengan kerusakan lingkungan yang disebut dengan pre-industrial economic; kedua, tahap industrial economic, dan ketiga, tahap post-industrial economic atau pasca industri. Mulanya, industialisasi berawal dari industri kecil dan kemudian berkembang menjadi industri besar. Pergerakan ini akan meningkatan sumber daya alam dan peningkatan degradasi lingkungan. Setelah itu, industrialisasi akan memperluas perannya dalam pembentukan produk nasional domestik. Hal ini terjadi pada tahap kedua, bersamaan dengan hal tersebut adanya investasi yang mendorong terjadinya transformasi ekonomi dari sektor pertanian ke sektor industri.

Pada tahap ketiga, terjadi pergerakan transformasi ekonomi dari sektor industri ke sektor jasa. Pergerakan ini akan diikuti dengan penurunan polusi udara yang sejalan dengan peningkatan pendapatan. Bersamaan dengan hal itu, permintaan terhadap kualitas lingkungan berjalan seiring dengan peningkatan pendapatan. Masyarakat mulai mampu membayar kerugian lingkungan yang timbul akibat dari kegiatan ekonomi.

\section{Eksternalitas Lingkungan}

Kerusakan lingkungan dalam Ilmu Ekonomi disebabkan oleh kegiatan manusia, secara spesifik disebut eksternalitas. Kerugian atau keuntungan yang di derita atau dinikmati perilaku ekonomi karena tindakan pelaku ekonomi lain disebut eksternalitas. Eksternalitas timbul ketika beberapa kegiatan dari produsen dan konsumen memiliki pengaruh yang tidak langsung dan eksternalitas yang timbul bisa positif maupun negatif.

Eksternalitas positif terjadi ketika kegiatan yang dilakukan oleh seseorang ataupun kelompok memberikan manfaat pada individu atau kelompok lain (Sankar, 2008). Sedangkan eksternalitas negatif terjadi ketika proses pabrik di suatu wilayah menimbulkan dampak negatif seperti membuang limbah disungai yang berakibat pada pencemaran air atau menimbulkan polusi udara sehingga terjadi pencemaran lingkungan. Penduduk disekitar pabrik akan menanggung biaya eksternal dari kegiatan ekonomi tersebut berupa masalah kesehatan, kesulitan mengakses air bersih, serta berkurangnya udara bersih.

Polusi dalam air tidak hanya disebabkan oleh limbah pabrik, akan tetapi juga disebabkan oleh penggunaan pestisida dan pupuk berbahan kimia dalam proses produksi pertanian. Kemudian, polusi udara tidak hanya ditimbulkan oleh kendaraan bermotor dan asap pabrik melainkan juga ditimbulkan oleh pembakaran lumbung padi yang sampai saat ini masih sering dilakukan oleh para petani.

Eksternalitas positif terjadi ketika manfaat sosial marginal lebih besar dari biaya individu, oleh sebab itu output individu lebih kecil daripada output sosial. Sementara, eksternalitas negatif terjadi saat biaya sosial marginal lenih besar dari biaya individu marginal. Oleh sebab itu, tingkat output individu lebih besar dari output sosial (Sankar, 2008). 


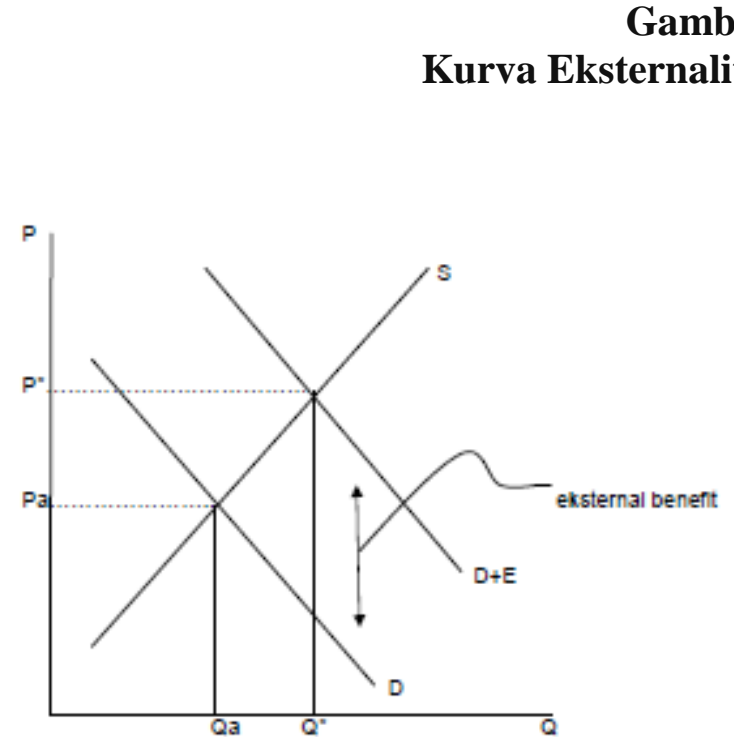

a. Eksternalitas Positif

Sumber: Pyndick, (1998)

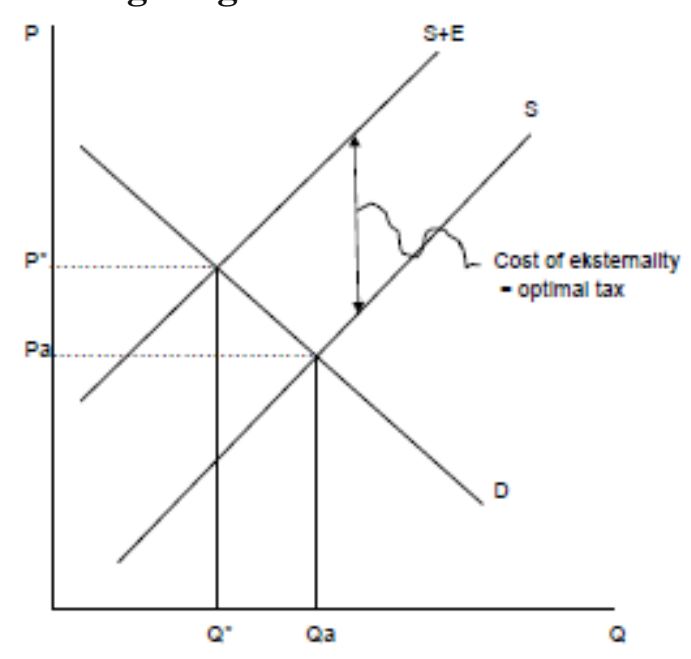

b. Eksternalitas Negatif

\section{METODE PENELITIAN}

\section{Definisi Oprasional Variabel}

Definisi operasional merupakan penjelasan dari seluruh variabel yang digunakan dalam penelitian ini dengan tujuan agar tidak terjadi kesalahpahaman bagi pembaca dalam mengartikan makna penelitian. Berdasarkan variabel yang digunakan dimana nilai Indeks Kualitas Lingkungan Hidup (ILKH) sebagai baku mutu yang mencerminkan kondisi lingkungan. Selain itu, juga dapat digunakan sebagai bahan informasi dalam mendukung pengambilan kebijakan yang berkaitan erat dengan perlindungan pengelolahan lingkungan hidup. Nilai IKLH diperoleh dari perhitungan penjumlahan indikator lingkungan seperti kualitas air, udara serta tutupan lahan, dimana masing - masing indikatot tersebut dikalikan 30\%. Secara konseptual nilai IKLH bersifat komparatif, artinya nilai satu provinsi relatif terhadap provinsi lainnya. Masing - masing provinsi memberi kontribusi terhadap nasional secara proposional.

Sementara itu, variabel ekonomi seperti sektor Industri, Pertanian dan Transportasi merupakan hasil Produk Domestik Regional Bruto Menurut Lapangan Usaha Atas Dasar Harga Berlaku dengan pendekatan produksi. Semua variabel yang digunakan dalam penelitian ini menggunakan satuan dalam bentuk persen.

\section{Jenis dan Sumber Data}

Data yang digunakan dalam penelitian ini berupa gabungan antara data time series dan cross section yang disebut dengan data panel selama lima tahun terakhir. Data cross section berupa $38 \mathrm{Kab} / \mathrm{Kota}$ di Provinsi Jawa Timur, sementara time series sebanyak lima tahun yaitu tahun 2013 - 2017.

Data yang digunakan adalah data sekunder, data tersebut bersumer dari Badan Pusat Statistik Jawa Timur dan Kementrian Lingkungan Hidup Indonesia 
serta jurnal - jurnal yang mendukung dan berhubungan dengan penelitian ini serta buku - buku referensi yang digunakan untuk mendukung penelitian ini.

\section{Metode Analisis}

Model yang digunakan dalam penelitian ini adalah Vector Error Corection Models (VECM). Dimana hasil dari estimasi ini nantinya dapat melihat hubungan dalam jangka pendek maupun jangka panjag antar variabel terikat dan variabel bebas. Vector Error Corection Models (VECM) merupakan bentuk VAR yang terekstrisi digunakan untuk data yang tidak stasioner pada tingkat level namun terdapat kemungkinan adanya kointegrasi (Enders, 2004). Spesifikasi model VECM secara umum, sebagai berikut (Siregar and Ward, 2000) :

$$
\Delta Y_{t}=\sum_{i=1}^{k-1} \Gamma i \Delta y_{t-1}+\mu_{0}+\mu_{1} t+\alpha \beta \gamma_{t-1}+\varepsilon_{t}
$$

Dimana:

$\Delta Y_{t} \quad=$ vektor yang berisi variabel yang dianalisis dalam penelitian

$\mu_{0} \quad=$ vektor intercept

$\mu_{1} \quad=$ vektor koefisien regresi

$\mathrm{t} \quad=$ time trend

$\alpha \quad=$ matriks loading (penyesuaian)

$Y_{t-1}=$ variabel in-level

$k-1 \quad=$ ordo koefisien regresi

$\varepsilon_{t} \quad=$ error term

Kemudian, metode yang dipilih adalah Granger Causality, dimana sebuah metode untuk mengetahui variabel terikat dapat dipengaruhi oleh variabel bebas ataukah sebaliknya. Hubungan seperti ini disebut hubungan timbal balik. Spesifikasi metode Granger Causality di formulasikan sebagai berikut (Junaidi, 2012) :

$$
\begin{aligned}
& X_{t}=\sum_{i=l}^{m} a_{i} Y_{t-i}+\sum_{j=l}^{n} \beta_{j} X_{t-j}+U_{t 1} \\
& Y_{t}=\sum_{i=l}^{m} \lambda_{i} X_{t-i}+\sum_{j=l}^{m} \delta_{j} Y_{t-j}+U_{t 2}
\end{aligned}
$$

Dimana:

Xt = Laju Pertumbuhan PDRB sektor Pertanian, Industri, dan Transportasi (persen)

Yt = Indeks Kualitas Lingkungan Hidup, Indeks Kualitas Udara dan Air (persen)

$\mathrm{M} \quad=$ Jumlah lag

$\mathrm{Ut}_{\mathrm{t} 1} \mathrm{U}_{\mathrm{t} 2}=$ Variabel pengganggu

$\alpha, \beta, \lambda, \delta=$ Koefisien masing - masing variabel

diasumsikan bahwa gangguan $\mathrm{U}_{\mathrm{t} 1}$ dan $\mathrm{Ut}_{\mathrm{t} 2}$ tidak berkorelasi. 
Pada Uji Granger Causality terdapat empat hipotesis, antara lain:

a. Jika $\sum_{i-l}^{m} a_{i} \neq 0$ dan $\sum_{i-l}^{m} \delta_{j}=0$ maka terdapat kausalitas satu arah anatara variabel Kualitas Lingkungan Hidup terhadap PDRB Sektor Pertanian, Industri dan Sektor Transportasi.

b. Jika $\sum_{i-l}^{m} a_{i}=0$ dan $\sum_{i-l}^{m} \delta_{j} \neq 0$ maka maka terdapat kausalitas satu arah anatara variabel PDRB Sektor Pertanian, Industri dan Sektor Transportasi terhadap variabel Kualitas Lingkungan Hidup.

c. Jika $\sum_{i-l}^{m} a_{i}=0$ dan $\sum_{i-l}^{m} \delta_{j}=0$ maka terdapat kausalitas dua arah antara variabel PDRB Sektor Pertanian, Industri dan Sektor Transportasi terhadap Kualitas Lingkungan Hidup atau sebaliknya.

d. Jika $\sum_{i-l}^{m} a_{i} \neq 0$ dan $\sum_{i-l}^{m} \delta_{j} \neq 0$ maka tidak terdapat kausalitas dua arah antara variabel Kualitas Lingkungan Hidup dan PDRB Sektor Pertanian, Industri dan Sektor Transportasi.

\section{HASIL DAN PEMBAHASAN \\ Pemilihan Model Terbaik}

Model terbaik didapat dari hasil uji kointegrasi, dimana apabila data menunjukkan hasil kointegrasi maka model yang dipakai adalah VECM, namun apabila data tidak kointegrasi maka model yang digunakan adalah VAR. Hasil dari uji kointegrasi menunjukan semua data terkointegrasi maka model yang digunakan adalah VECM.

Setelah itu, dilakukan uji stabilitas model untuk mengetahui apakah model tersebut valid dan stabil jika digunakan dalam penelitian ini. Hasil dari uji stabilitas model menunjukkan bahwa nilai roots dan modulus sama dengan satu, artinya model VECM valid dan stabil untuk digunakan dalam penelitian ini.

\section{Hasil dan Pembahasan}

Analisis data pada penelitian ini menggunakan model terbaik yaitu Vector Error Corection (VECM). Data yang diolah adalah data laju pertumbuhan PDRB sektor Industri, Pertanian dan Transportasi di Jwa Timur dengan rentang waktu lima tahun yaitu 2013 - 2017. Tujuan penelitian ini adalah untuk mengetahui seberapa besar hubungan antara laju pertumbuhan PDRB ketiga sektor yang menjadi fokus pada penelitian ini dengan Indeks Kualitas Lingkungan Hidup di Jawa Timur. Kemudian, seberapa besar dampak yang ditimbulkan dalam jangka pendek maupun jangka panjang serta apakah Hypotesis Environental Kuznet Curve terbukti di Jawa Timur.

Pada penelitian ini, menggunakan nilai alpha sebesar 0.05 , lebih jelasnya hasil akan diuraikan dibawah ini yang mana sudah dilakukan serangkaian tahapan dan sesuai dengan prosedur kajian ilmiah.

Tabel.3 Sektor Industri terhadap IKLH

\begin{tabular}{lccr}
\hline \hline Null Hypothesis: & Obs & F-Statistic & Prob. \\
\hline \hline XT1 does not Granger Cause IKLH & 152 & 0.11742 & 0.9010 \\
IKLH does not Granger Cause XT1 & & 3.41903 & 0.0470 \\
\hline \hline
\end{tabular}


Hasil Granger Causality Test pada tabel.3 menunjukkan bahwa $\sum_{i-l}^{m} a_{i} \neq 0$ dan $\sum_{i-l}^{m} \delta_{j}=0$ artinya, terdapat hubungan kausalitas satu arah antara Indeks Kualitas Lingkungan Hidup terhadap sektor Industri sebesar $0.0470 \%$ signifikan dalam taraf 5\%. Hasil penelitian ini sejalan dengan penelitian dari Rizky Adi (2006) di Pulau Sumatera dimana hasil yang di dapat juga menunjukkan bahwa sektor Industri memiliki hubungan kausalitas signifikan dalam taraf $5 \%$.

Tabel.4 Sektor Pertanian terhadap IKLH

\begin{tabular}{lcrr}
\hline \hline Null Hypothesis: & Obs & F-Statistic & Prob. \\
\hline \hline XT2 does not Granger Cause IKLH & 64 & -0.78078 & 0.0000 \\
IKLH does not Granger Cause XT2 & & 0.00000 & 0.0000 \\
\hline \hline
\end{tabular}

Hasil Granger Causality Test pada tabel.4 menunjukkan bahwa $\sum_{i-l}^{m} a_{i}=0$ dan $\sum_{i-l}^{m} \delta_{j}=0$ artinya, terdapat hubungan kausalitas dua arah antara variabel sektor Pertanian terhadap Indeks Kualitas Lingkungan Hidup maupun sebaliknya sebesar $0.0000 \%$ signifikan dalam taraf 5\%. Hasil ini sesuai dengan penelitian Idris (2012) di Indonesia, dimana pada fase awal pergerakan dari sektor Pertanian ke sektor Industri dampak penggunaan faktor produksi yang tidak ramah lingkungan penggunaan sumber daya alam berlebihan serta penggunaan pupuk berbahan kimia pada kegiatan bercocok tanam akan berdampak pada kerusakan lingkungan hidup.

Fakta dilapangan, dimana pertumbuhan pendapatan pada sektor ini akan diikuti dengan penurunan IKLH. Peralihan sektor dari pertanian industri terjadi eksplorasi besar - besaran terhadap penggunan sumber daya alam dan sampai batas tertentu akan berdampak pada degradasi lingkungan.

Tabel.5 Sektor Transportasi terhadap IKLH

\begin{tabular}{lccc}
\hline \hline Null Hypothesis: & Obs & F-Statistic & Prob. \\
\hline \hline XT3 does not Granger Cause IKLH & \multirow{2}{*}{48} & 0.77258 & 0.0000 \\
IKLH does not Granger Cause XT3 & & 0.01247 & 0.0000 \\
\hline \hline
\end{tabular}

Hasil Granger Causality Test pada tabel.5 menunjukkan bahwa $\sum_{i-l}^{m} a_{i}=0$ dan $\sum_{i-l}^{m} \delta_{j}=0$ artinya, terdapat hubungan timbal balik dua arah antara sektor Transportasi terhadap Indeks Kualitas Lingkungan Hidup sebesar 0.0000\% signifikan dalam taraf 5\%. Hubungan ini tercemin dari padatnya arus lalu lintas yang sejalan dengan peningkatan pendapatan pada sektor jasa transportasi di Jawa Timur.

Sementara itu, hasil estimasi VECM pada tabel.7 hampir seluruh variabel menunjukkan pengaruh negatif dalam jangka pendek maupun jangka panjang, namun dampaknya sangat kecil sekali. Pada sektor Industri $\left(X t_{1}\right)$ pada jangka pendek berpengaruh sebesar -7.31E-16\% dan pada jangka panjang sebesar $-2.56 \mathrm{E}-16 \%$. Fenomena hubungan negatif ini mengindikasikan bahwa, apabila terjadi kenaikan pada laju pertumbuhan PDRB Sektor Industri akan menyebabkan penurunan pada Indeks Kualitas Lingkungan Hidup di Provinsi Jawa Timur. 
Hubungan jangka pendek pada sektor Pertanian $\left(X t_{2}\right)$ sebesar $-3.86 \mathrm{E}-16 \%$ begitu juga pada jangka panjang juga memiliki pengaruh negatif sebesar $-6.10 \mathrm{E}-$ 17\%. Artinya, apabila terjadi kenaikan sebesar satu persen pada laju pertumbuhan sektor Pertanian akan menurunkan Indeks Kualitas Lingkungan Hidup sebesar $3.86 \mathrm{E}-16 \%$ pada jangka pendek dan pada jangka panjang sebesar $-6.10 \mathrm{E}-17 \%$. Sedangkan pada sektor Transportasi, pada jangka pendek maupun jangka panjang memiliki pengaruh negatif sebesar -4.36E-16 pada jangka pendek dan pada jangka panjang sebesar -8.93E-16. Fenomena ini mengindikasikan bahwa apabila terjadi kenaikan satu persen pada laju pertumbuhan sektor Transportasi akan menurunkan Kualitas Lingkungan Hidup di Jawa Timur dalam jangka pendek maupun jangka panjang.

Tabel.6 Hasil Estimasi VECM Jangka Pendek dan Jangka

\section{Panjang}

\begin{tabular}{|c|c|c|c|c|}
\hline Cointegrating Eq: & CointEq1 & & & \\
\hline $\operatorname{IKLH}(-1)$ & 1.000000 & & & \\
\hline $\mathrm{XT} 1(-1)$ & $\begin{array}{c}-2.56 \mathrm{E}-16 \\
(3.8 \mathrm{E}-09) \\
{[6.8 \mathrm{e}-08]}\end{array}$ & & & \\
\hline $\mathrm{XT} 2(-1)$ & $\begin{array}{r}-6.10 \mathrm{E}-17 \\
(4.2 \mathrm{E}-09) \\
{[-1.4 \mathrm{e}-08]}\end{array}$ & & & \\
\hline XT3(-1) & $\begin{array}{c}-8.93 \mathrm{E}-16 \\
(2.9 \mathrm{E}-09) \\
{[3.1 \mathrm{e}-07]}\end{array}$ & & & \\
\hline C & -60.72000 & & & \\
\hline Error Correction: & $\mathrm{D}(\mathrm{IKLH})$ & $\mathrm{D}(\mathrm{XT} 1)$ & $\mathrm{D}(\mathrm{XT} 2)$ & $\mathrm{D}(\mathrm{XT} 3)$ \\
\hline CointEq1 & $\begin{array}{r}-1.361623 \\
(2.3 \mathrm{E}-09) \\
{[-5.8 \mathrm{e}+08]}\end{array}$ & $\begin{array}{r}0.297318 \\
(0.03919) \\
{[7.58566]}\end{array}$ & $\begin{array}{r}-0.331812 \\
(0.03601) \\
{[-9.21528]}\end{array}$ & $\begin{array}{r}0.201572 \\
(0.04408) \\
{[4.57333]}\end{array}$ \\
\hline $\mathrm{D}(\mathrm{IKLH}(-1))$ & $\begin{array}{r}0.835204 \\
(1.6 \mathrm{E}-16) \\
{[5.1 \mathrm{e}+15]}\end{array}$ & $\begin{array}{r}-0.321510 \\
(0.06545) \\
{[-4.91201]}\end{array}$ & $\begin{array}{r}0.207200 \\
(0.06013) \\
{[3.44586]}\end{array}$ & $\begin{array}{r}-0.108283 \\
(0.07360) \\
{[-1.47114]}\end{array}$ \\
\hline $\mathrm{D}(\mathrm{XT} 1(-1))$ & $\begin{array}{r}-7.31 \mathrm{E}-16 \\
(1.7 \mathrm{E}-16) \\
{[-4.29187]}\end{array}$ & $\begin{array}{r}-0.339813 \\
(0.06822) \\
{[-4.98133]}\end{array}$ & $\begin{array}{r}-0.038916 \\
(0.06267) \\
{[-0.62098]}\end{array}$ & $\begin{array}{r}0.118092 \\
(0.07671) \\
{[1.53941]}\end{array}$ \\
\hline $\mathrm{D}(\mathrm{XT2} 2(-1))$ & $\begin{array}{r}-3.86 \mathrm{E}-16 \\
(1.8 \mathrm{E}-16) \\
{[-2.08884]}\end{array}$ & $\begin{array}{c}0.023995 \\
(0.07403) \\
{[0.32410]}\end{array}$ & $\begin{array}{r}-0.273264 \\
(0.06801) \\
{[-4.01782]}\end{array}$ & $\begin{array}{r}0.105867 \\
(0.08325) \\
{[1.27160]}\end{array}$ \\
\hline $\mathrm{D}(\mathrm{XT3}(-1))$ & $\begin{array}{r}-4.36 \mathrm{E}-16 \\
(1.5 \mathrm{E}-16) \\
{[-2.97651]}\end{array}$ & $\begin{array}{r}-0.050784 \\
(0.05869) \\
{[-0.86524]}\end{array}$ & $\begin{array}{r}-0.057616 \\
(0.05392) \\
{[-1.06856]}\end{array}$ & $\begin{array}{r}-0.251762 \\
(0.06600) \\
{[-3.81443]}\end{array}$ \\
\hline
\end{tabular}




C $\begin{array}{rrrr}-0.745376 & 0.674471 & -1.211213 & 0.191195 \\ (4.9 \mathrm{E}-16) & (0.19597) & (0.18003) & (0.22037) \\ {[-1.5 \mathrm{e}+15]} & {[3.44174]} & {[-6.72790]} & {[0.86760]}\end{array}$

Jika hasil VECM dari Indeks Kualitas Lingkungan Hidup dan ketiga sektor tersebut di formulasikan kedalam model VECM maka seperti berikut :

$\mathrm{IKLH}=0.835204 \mathrm{IKLH}+(-2.56 \mathrm{E}-16 \mathrm{INDSTR})+(-6.10 \mathrm{E}-17 \mathrm{PRTNIAN})+$ $(-8.93 \mathrm{E}-16 \mathrm{TRNSPORT})$

Hasil negatif yang dijelaskan oleh estimasi VECM pada jangka pendek dan jangka jangka panjang merupakan akibat dari proses kegiatan produksi yang menghasilkan eksternalitas negatif pada lingkungan hidup. Kegiatan produksi pada sektor Industri menghasilkan limbah padat maupun cair yang berdampak pada kerusakan lingkungan seperti pencemaran udara akibat asap pabrik, pembuangan limbah padat yang mengakibatkan udara tidak sedap serta pencemaran air akibat dari pembuangan sisa produksi berupa limbah cair. Pada gilirannya aktivitas kegiatan pada sektor ini berdampak pada masyarakat sekitar. Dengan kata lain, biaya sosial lebih tinggi daridapa biaya marginal - eksternalitas negatif.

Proses bercocok tanam pada sektor Pertanian menggunakan pupuk kimia dapat mencemari air yang berakibat pada penurunan beban kandungan air. Penggunaan pupuk kimia dalam jangkapanjang juga dapat berakibat pada penurunan kandungan pangan yang dihasilkan pada sektor ini. Secara tidak langsung akan berakibat pada kesehatan manusia. Semestra itu, sektor Transportasi merupakan sektor yang dapat membantu kelancaran distribusi barang hasil dari kegiatan produksi yang dilakukan sektor pertanian dan industri. Dalam jangka panjang padatnya arus lalu lintas akan mengakibatkan pada penurunan kualitas udara.

Secara garis besar, antara hubungan Indeks Kualitas Lingkungan Hidup, terhadap sektor Industri, Pertanian dan Transportasi dapat ditarik kesimpulan bahwa dari teori Hypotesis Environmental Kuznets Curve serta bukti empiris yang ada, dimana bukti empiris percaya atas hubungan bentuk regresi dari kualitas lingkungan terhadap tingkat pendapatan. Hubungan empiris menganggap bahwa proses awal pembangunan yang dibarengi dengan pertumbuhan ekonomi dengan sendirinya akan menjadikan obat mujarab bagi degradasi lingkungan.

Dari hasil Hypotesis Environmental Kuznet Curve (EKC) menbuktikan bahwa hampir semua variabel menyerupai kurva berbentuk $U$-terbalik yang melandai. Fenomena ini menjelaskan bahwa kurva berbentuk $U$-terbalik sebagai bentuk atas perubahan skala, komposisi, dan teknik yang muncul pada proses pembangunan ekonomi yang dibarengi dengan tingkat pertumbuhan ekonomi, (studi Grossman, 1995).

Teori Environmental Kuznet Curve (EKC) menyatakan bahwa pada tahap awal pertumbuhan akan meningkatkan degradasi lingkungan. Fakta pada lapangan, dimana tren pertumbuhan pada sektor pertanian di Jawa Timur terus mengalami peningkatan pendapatan dari tahun ke tahun. Fenomena ini menunjukkan bahwa apabila laju pertumbuhan pada jenis lapangan usaha mengalami pertumbuhan maka hal tersebut menunjukkan bahwa pembangunan di wilayah tersebut mengikuti tren 
pertumbuhan yang positif. Tingginya tingkat produksi yang dilakukan sektor Industri berakibat pada tingginya penggunan sumber daya alam yang sejalan dengan pertumbuhan tingkat pendapatan pada sektor Industri. Artinya, semakin besar kegiatan yang dilakukan sektor industri maka semakin besar pula sektor Pertanian menyediakan bahan baku, akibatnya terjadi eksplorasi besar besaran pada sumber daya alam dan pada gilirannya akan berdampak pada kerusakan lingkungan hidup.

Kegiatan ekonomi yang bersifat ekstraksi, fabrikasi maupun konsumsi akan mempengaruhi kemampuan alam dalam penyedia sumber daya alam (Gupito, 2012). Artinya, daya dukung lingkungan bukan hanya terletak pada kemampuang lingkungan sebagai pemenuh kebutuhan manusia, tetapi juga kepada kemampuan menerima beban pencemaran dalam proses pembangunan dan kegiatan produksi (Kementrian Lingkungan Hidup, 2010).

Dilihat dari fenomena yang terjadi dan beberapa fakta dilapangan serta hasil dari penelitian yang ada, bahwa dapat ditarik benang merah dimana fokus utama pemerintah adalah pada peningkatan produksi yang pada gilirannya akan meningkatkan pendapatan pada ketiga sektor lapangan usaha Industri, Pertanian, dan Transportasi tanpa memperhatikan aspek lingkungan. Oleh sebab itu, hubungan Indeks Kualitas Lingkungan Hidup terhadap sektor Industri dan Transportasi menyerupai $U$-terbalik yang melandai, artinya pada awal proses pembangunan ekonomi pada sektor Industri dan Transportasi akan diikuti dengan peningkatan pendapatan yang dibarengi dengan kerusakan lingkungan hidup dan pada titik tertentu peningkatan pendapatan tersebut dibarengi dengan permintaan kualitas lingkungan hidup dan pada gilirannya ketika titik batas tersebut tercapai, kegiatan pada kedua sektor ini dibarengi dengan membaiknya kualitas lingkungn yang sangat lambat. Sementara pada Sektor Pertanian Hypotesis Environmental Kuznets Curve tidak terbukti. Hubungan sektor Pertanian dengan Indeks Kualitas Lingkungan Hidup menyerupai huruf U yang landai. Artinya, pada awal proses pembangunan pada sektor ini diikuti dengan penurunan kualitas lingkungan pada batas tertentu dengan pendapatan yang relatif kecil. Ketika pada titik tertentu, pendapatan naik diikuti dengan penurunan kualitas lingkungan hidup. Setelah batas tertentu tercapai, peningkatan pendapatan pada sektor ini diikuti kembali dengan peningkatan indeks kualitas lingkungan hidup yang sangat lambat.

Pertumbuhn ekonomi pada titik tertentu akan membawa pada kesadaran masyarakat akan pentingnya kualitas lingkungan hidup yang layak. Pada titik ini, terjadi peningkatan pendapatan yang disertai dengan penggunaan sumber daya alam yang tinggi, akumulasi limbah padat maupun cair, pencemaran udara yang pada gilirannya akan membawa kepada kerusakan lingkungan dan permintaan terhadap penurunan kerusakan lingkungan sangat lambat.

\section{KESIMPULAN}

Untuk terciptanya pembangunan yang berkelanjutan dan terlindungnya kelestarian alam, pemerintah sebagai pemangku kebijakan diharapkan untuk lebih memperhatikan kembali regulasi yang menyangkut tentang pengelolahan sumber daya dan lingkungan hidup. Bersamaan dengan hal itu, pemerintah yang memiliki kedudukan tertinggi atas regulasi dan kebijakan kebijakan yang dibuat agar dapat merumuskan suatu kebijakan yang mampu meningktkan pendapatan masyarakat. 
Nantinya, akan berujung pada kemampuan masyarakat untuk membayar kerugian kerusakan lingkungan akibat dari kegiatan ekonomi dan pada gilirannya masyarakat mulai mengkorbankan konsumsinya demi terlindungnya lingkungan hidup.

Adanya regulasi dan kebijakan tersebut, tentu perlu suatu insentif lain seperti gerakan penghijauan atau pembangunan ruang hijau di daerah pemukiman, duta lingkungan yang nantinya dapat memberikan edukasi tentang pengelolahan sumber daya dan lingkungan hidup. Gerakan tersebut tidak luput dari pengawasan instansi terkait yaitu Kementrian Lingkungan Hidup. Hal tersebut dilakukan tidak lain untuk membantu memperkuat regulasi dan kebijakan yang sudah ada. Se-hingga dapat menciptakan pembangunan ekonomi yang berkelanjutan.

\section{DAFTAR PUSTAKA}

Badan Pusat Statistik Provinsi. 2017. Publikasi Statistik Produk Domestik Regional Bruto. Jawa Timur: Hal. 93-147.

Kementrian Pengelolahan Lingkungan Hidup Jawa Timur. 2017. Publikasi Dokumen Informasi Dinas Lingkungan Hidup Provinsi Jawa Timur. Hal 3, 17, 28-43.

Gujarati, Damador. 2003. Ekonometrika Dasar. Terjemahan Sumarno Zain: Jakarta. Hal 31-42.

Gujarati, D. Porter Dawn C. 2009. Basic Econometrics 5th edition: McGraw-Hill. Hal 149-152.

Pindyck, R. Dan Rubinfeld, D. 2013. Microeconomic. New Jersey: Prentice Hall. Hal 63-84

N.H.T Siahan. 2004. Ekologi Pembangunan dan Hukum Tata Lingkungan. Erlangga: Jakarta. Hal 18-29.

Todaro, Michael P. dan Stephen C. Smith. 2003. Economic Development 8th edition. England: Person Education Limitide. Hal 201-216.

Idris. 2012. "Evironmental Kuznets Curve: Bukti Empiris Hubungan antara Pertumbuhan Ekonomi dan Kualitas Lingkungan di Indonesia”. Jurnal Economic: FE UNP. Hal 5-12.

Dinda, S. 2004. "Environmental Kuznets Curve Hypotesis: A Survey". Unit Penelitian Ekonomi: Institusi Statistika India. Hal 38-72.

Gupito, Katrin Retno. 2004. "Keterkaitan PDRB perkaita dari Sektor Industri, Transportasi, Pertanian dan Kehutanan Terhadap Kualitas Lingkungan”. FE: Universitas Diponegoro Semarang. Hal 33-54.

Norman, Robert T. Dan Cathrine S, 2004. "Does the Environmental Kuznets Curve Describe How Individual Countries Behave?”. Departement od Economic University of California. Hal 92-111 